\title{
Lateral water exchange between shelf-margin upwelling and Kuroshio waters influences phosphorus stress in microphytoplankton
}

\author{
Hung-Chun Liu ${ }^{1}$, Gwo-Ching Gong ${ }^{2}$, Jeng Chang ${ }^{1,2, *}$ \\ ${ }^{1}$ Institute of Marine Biology and ${ }^{2}$ Institute of Marine Environmental Chemistry and Ecology, \\ National Taiwan Ocean University, Keelung 20224, Taiwan, ROC
}

\begin{abstract}
Phosphorus stress in microphytoplankton was investigated in an upwelling system and an adjacent segment of the Kuroshio Current in the southern East China Sea. In June, August, and September 2007, 3 cruises were conducted, and alkaline phosphatase activity (APA) and the maximum quantum efficiency of photosynthesis $\left(F_{V} / F_{m}\right)$ were measured along a cross-shelf cruise track from the mid-shelf to the Kuroshio Current. In June and August, values of APA ranged from 1.41 to 9.56 pmol $\mathrm{PO}_{4}{ }^{3-}(\mu \mathrm{g} \text { chlorophyll [chl] } a)^{-1} \mathrm{~min}^{-1}$, and those of $F_{V} / F_{m}$ ranged from 0.28 to 0.45 in surface waters. In September, a strong salinity front appeared between the upwelling zone and Kuroshio waters. Low APA values of 1.23 to $8.08 \mathrm{pmol} \mathrm{PO}_{4}{ }^{3-}(\mu \mathrm{g} \mathrm{chl} \mathrm{a})^{-1} \mathrm{~min}^{-1}$ were observed in the upwelling region, and high values of 34.9 to $77.6 \mathrm{pmol} \mathrm{PO}_{4}{ }^{3-}(\mu \mathrm{g} \mathrm{chl} \mathrm{a})^{-1} \mathrm{~min}^{-1}$ were observed in Kuroshio waters. A significant correlation between the APA and $F_{V} / F_{m}$ only occurred in September, and a possible event of phosphate stress in Kuroshio waters was supported by high APA values and changes in the microphytoplankton species composition. Our results suggest that phosphorus stress in microphytoplankton is related to the magnitude of horizontal water exchange between the Kuroshio and upwelling waters.
\end{abstract}

KEY WORDS: Alkaline phosphatase $\cdot F_{v} / F_{m} \cdot$ Kuroshio $\cdot$ Water exchange $\cdot$ Phosphorus stress $\cdot$ Microphytoplankton · East China Sea · Upwelling

Resale or republication not permitted without written consent of the publisher

\section{INTRODUCTION}

Off the northeastern coast of Taiwan, there is a persistent upwelling system caused by the local curvature of the continental slope, which affects the flow of the Kuroshio Current (Chern et al. 1990, Liu et al. 1992). This upwelling is one of the major nutrient sources for the East China Sea (ECS), and supports abundant microphytoplankton ( $>20 \mu \mathrm{m}$ in size) that contribute as much as $57 \%$ to the depth-integrated primary productivity (Chen 2000). Horizontal exchanges between the oligotrophic Kuroshio and the upwelling system vary with time and are apparently influenced by climatic as well as hydrographic events such as the summer monsoon and movements of the Kuroshio axis (Gong et al. 1992, Liu et al. 1992).
In such an upwelling system, nutrients rise to the euphotic zone and are then transported radially via horizontal exchange with adjacent oligotrophic waters (Gong et al. 1992). High concentrations of nutrients, together with optimal light and temperature, allow phytoplankton to thrive (Chen 1994, Chiang et al. 1997, Dugdale et al. 2006). These processes lead to a more dominant grazing food chain and promote the sinking of particulate organic matter (Falkowski 2002, Hung et al. 2009). However, as the upwelled water ages or when cells drift far from the upwelling center, phytoplankton eventually experience nutrient deficiencies. For example, in the upwelling area off the Oregon coastal ocean of the US Northwest and Izu Peninsula in Japan, phytoplankton growth decreases when nutrients are depleted (Takahashi et al. 1986, 
Ruttenberg \& Dyhrman 2005). This is especially true for microphytoplankton since their lower surface area to volume ratio makes them more susceptible to nutrient deficiencies (Kiørboe 1993). As for which nutrient controls phytoplankton growth near the boundaries of an upwelling region, nitrate is the most frequently mentioned candidate (Chen 1994, 2000).

Kokkinakis \& Wheeler (1987) observed that upwelled nitrate was sufficient to support maximal growth rate (1 to $2 \mathrm{~d}^{-1}$ ) in upwelling systems of Oregon (USA), Benguela (Angola), and Peru. For the upwelling northwest of Taiwan, however, a significant relationship is lacking between surface nitrate concentrations and phytoplankton production (Chen et al. 1999, Gong et al. 2000). Since phosphate concentrations in the Kuroshio Surface Water are often below the detection limit (Chen et al. 1995), they may become a controlling factor for phytoplankton growth on specific occasions. Some understanding of the phosphorus status in phytoplankton is necessary to determine the role of this upwelling in the ECS.

The effect of P deficiency on phytoplankton growth is difficult to quantify (Smith \& Kalff 1981). Conventionally, nutrient limitations in phytoplankton have been mainly determined by the nutrient uptake rate, N/P ratio, and nutrient enrichment experiments (Perry 1976, Healey \& Hendzel 1980, Smith et al. 1986). Another method that is used to evaluate the phytoplankton P status is to measure alkaline phosphatase (AP) activity (APA). AP is an extracellular enzyme that hydrolyzes phosphomonoesters to generate inorganic phosphate (Perry 1972, Sebastián \& Niell 2004, Dyhrman \& Ruttenberg 2006). In many laboratory cultures and natural communities of phytoplankton, high APA is associated with low-P conditions, but it is greatly repressed when P is sufficient (Perry 1972, Ruttenberg \& Dyhrman 2005). Measuring APA is simple and does not require a long-term incubation (Perry 1972, 1976). However, APA is generally assumed to indicate a deficiency of bioavailable inorganic P and the attempt of cells to utilize organically bound P substrates (Cembella et al. 1982, Yamaguchi et al. 2005). Since large interspecific variations in APA are commonly observed, additional measurements of related parameters are suggested for a correct evaluation of the phytoplankton P status (Dyhrman \& Palenik 1999, Parkhill et al. 2001, Ruttenberg \& Dyhrman 2005, Dyhrman et al. 2007).

In this study, experiments were conducted to determine whether microphytoplankton experienced phosphorus stress in the transition zone between the upwelling area and Kuroshio Current in summer 2007. The APA assay was used to assess the in situ P status of microphytoplankton. In addition, since nutrient starvation in batch cultures usually causes significant decreases in the maximum quantum efficiency of photosynthesis $\left(F_{V} / F_{m}\right)$, this fluorescence-based measurement was performed to reveal the interactions between nutrient stress and photosynthesis (Kolber \& Falkowski 1993, Parkhill et al. 2001). In conjunction with an analysis of the species composition, our results indicate that the $\mathrm{P}$ status in microphytoplankton was influenced by the intensity of water exchange.

\section{MATERIALS AND METHODS}

Study sites and sampling. Data were obtained during cruises 1445 (June 8-11, 2007), 1463 (August 2-5, 2007), and 1473 (September 1-4, 2007) on board the RV 'Ocean Researcher II'. The study area was in the southern ECS, and sampling stations were arranged along a cross-shelf transect from mid-shelf (Stn 9) to the Kuroshio (Stn 14) (Fig. 1). The hydrographic parameters of temperature and salinity were measured with a CTD (SBE 911plus, SeaBird). Samples for nutrient concentrations were taken at specific depths using X-Niskin bottles (General Oceanics) mounted on a rosette sampler.

Microphytoplankton samples for APA measurements were collected by a double-trip plankton net (General Oceanics) with a $0.5 \mathrm{~m}$ mouth diameter and $20 \mu \mathrm{m}$ mesh size. The net was towed at a depth of either $3 \mathrm{~m}$ (surface samples) or $50 \mathrm{~m}$ for $10 \mathrm{~min}$ with the ship speed set to 1 knot. According to previous experience, the volume of water filtered during a net-tow with identical settings ranged from 5800 to 48000 l (Chang 2000), and net samples have been used for physiological measurements in the studies of microphytoplankton (Berman-Frank et al. 2001, Villareal 1992). Next, the content in the receiving bottle (cod end) was sequentially filtered through $20 \mu \mathrm{m}, 200 \mu \mathrm{m}$, and $1 \mathrm{~mm}$ mesh Nitex screens. The $1 \mathrm{~mm}$ mesh screen was designed to remove gelatinous zooplankton. The term 'microphytoplankton' in this report refers to organisms retained on the $20 \mu \mathrm{m}$ mesh screen with the understanding that some zooplankton were inevitably present. These microphytoplankton were washed off the screen and resuspended in 11 of seawater collected from the same depth. From each net tow, triplicate subsamples of $4 \mathrm{ml}$ each were used for the APA measurements. In addition, a $2 \mathrm{ml}$ sample was used for the $F_{V} / F_{m}$ measurement, and a $50 \mathrm{ml}$ subsample was used for phytoplankton enumeration. Another sample with a volume of 1 to $20 \mathrm{ml}$, depending on the concentration of microphytoplankton, was filtered onto a GF/F filter (Whatman) for chl a measurement. The GF/F filter was immediately packed into a tissue processing capsule (Electron Microscopy Sciences) and stored in liquid nitrogen until analysis. 

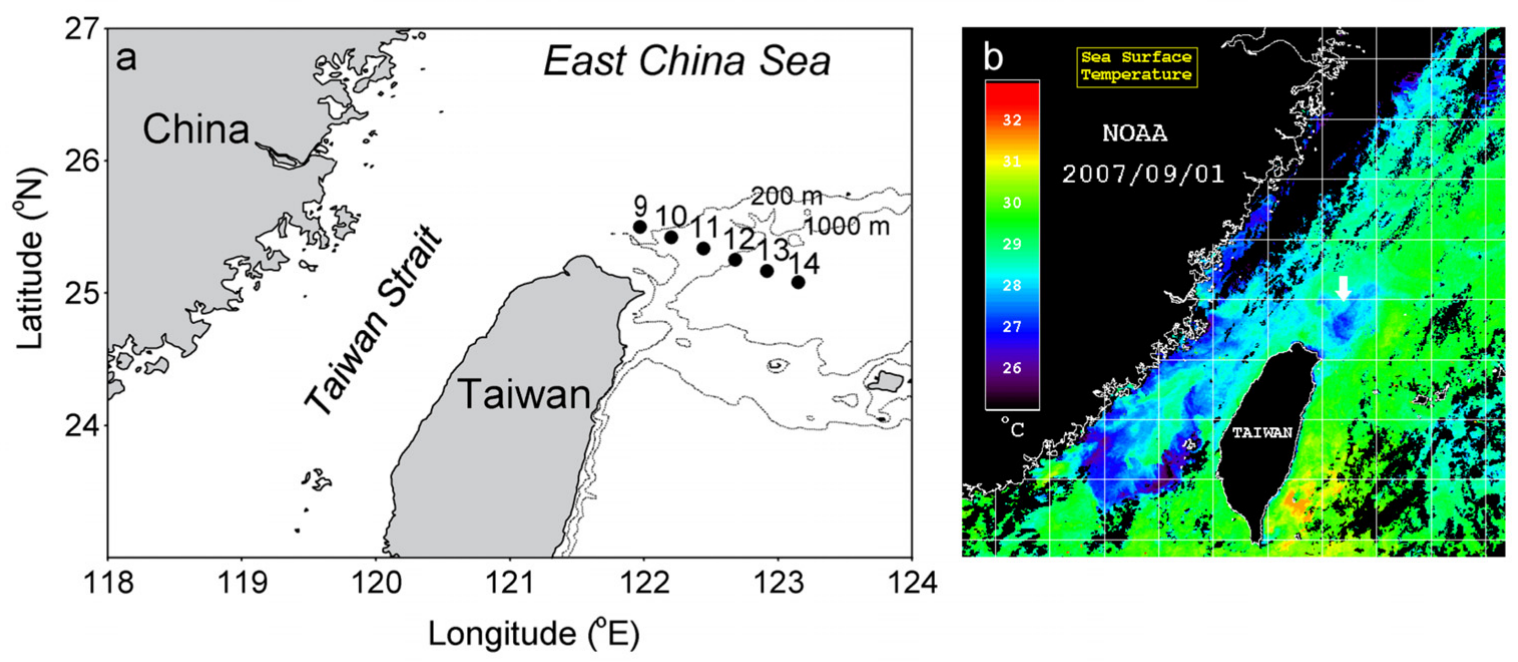

Fig. 1. Study area in the southern East China Sea. (a) Sampling Stns 9-14 during the 3 cruises conducted in June, August, and September 2007. (b) Sea surface temperatures on Sep 1, 2007 showing prominent upwelling (arrow) off the northeastern coast of Taiwan

Alkaline phosphatase activity (APA). Before measuring APA, $0.5 \mathrm{ml}$ of 3-O-methylfluorescein phosphate (Sigma) was added to a $4 \mathrm{ml}$ subsample as the AP substrate at a final concentration of $106 \mathrm{pmol} \mathrm{ml}^{-1}$. The subsample was then incubated in the dark at $25^{\circ} \mathrm{C}$ for $60 \mathrm{~min}$, and the fluorescence from the reaction product was measured with a fluorometer (10-AU, Turner Designs) equipped with a band-pass excitation filter of 390 to $500 \mathrm{~nm}$ and a band-pass emission filter of 510 to $700 \mathrm{~nm}$. The measurement was performed at both the beginning and end of the incubation period (Perry 1972).

$\boldsymbol{F}_{\boldsymbol{V}} / \boldsymbol{F}_{\boldsymbol{m}}$ measurements. Triplicates of $2 \mathrm{ml}$ microphytoplankton subsamples were placed in quartz cuvettes (NSG Precision Cells) and allowed to adapt to the dark for $15 \mathrm{~min}$. The cuvettes were then put into a Fluorescence Induction and Relaxation (FIRe) fluorometer (Satlantic) where a single turnover flash (at a wavelength of $450 \pm 15 \mathrm{~nm}$ ) with a duration of $80 \mu \mathrm{s}$ was applied to saturate photosystem (PS) II. Meanwhile, the minimum and maximum yields of chl a fluorescence $\left(F_{0}\right.$ and $\left.F_{m}\right)$ were recorded at the beginning and end of the single turnover flash, respectively. The maximum quantum efficiency of photosynthesis $\left(F_{V} / F_{m}\right)$ was then computed as $\left(F_{m}-F_{0}\right) / F_{m}$ (Campbell et al. 1998).

Determinations of nutrient and chl a concentrations. Nitrate was first reduced to nitrite with a cadmium wire activated with copper sulfate, and was then analyzed with a self-designed flow injection analyzer (Gong et al. 1992). The detection limit of nitrate was $0.3 \mu \mathrm{M}$. The concentration of phosphate in nutrient samples was measured by a modified version of the molybdenum blue method (Murphy \& Riley 1962, Pai et al. 1990). With the use of a $5 \mathrm{~cm}$ cuvette, the detec- tion limit was $0.01 \mu \mathrm{M}$. In addition, the chl a concentration was determined fluorometrically by the Welschmeyer (1994) non-acidification method.

Phytoplankton enumeration. Microphytoplankton subsamples for cell counts were preserved with acidic Lugol's solution (Smayda 1974) and counted with a Nikon Optiphot-2 microscope at 100×. At least 100 cells were counted in each sample, and microphytoplankton were identified to the generic level based on Tomas (1996).

\section{RESULTS}

\section{Hydrography and nutrient concentrations}

In June 2007, water temperatures along the cruise track were 28 to $29^{\circ} \mathrm{C}$ in the surface layer and 25 to $26^{\circ} \mathrm{C}$ at $50 \mathrm{~m}$ depth (Fig. 2a). Vertical sections of temperature $(\mathrm{T})$ and salinity $(\mathrm{S})$ revealed a mixed layer $\sim 50 \mathrm{~m}$ thick without the presence of any obvious upwelling event (Fig. 2a,d). The T-S curves indicated that salinities near the sea surface were low, but a strong horizontal gradient was lacking (Fig. 2g). The depth of the phosphocline was $\sim 5 \mathrm{~m}$ in the upwelling region and $\sim 100 \mathrm{~m}$ in the oligotrophic Kuroshio region (Fig. 3a,c). A similar trend was observed for nitrate and nitrite concentrations, and was especially obvious at $50 \mathrm{~m}$ depth (Table 1).

In August, an upwelling event was observed at Stn 12 as indicated by a dome of cold water at 20 to $80 \mathrm{~m}$ depths (Fig. 2b). Vertical sections of temperature and salinity revealed a mixed layer $\sim 20 \mathrm{~m}$ thick at Stns 11 and 12, which thickened to $30 \mathrm{~m}$ at Stns 13 and 


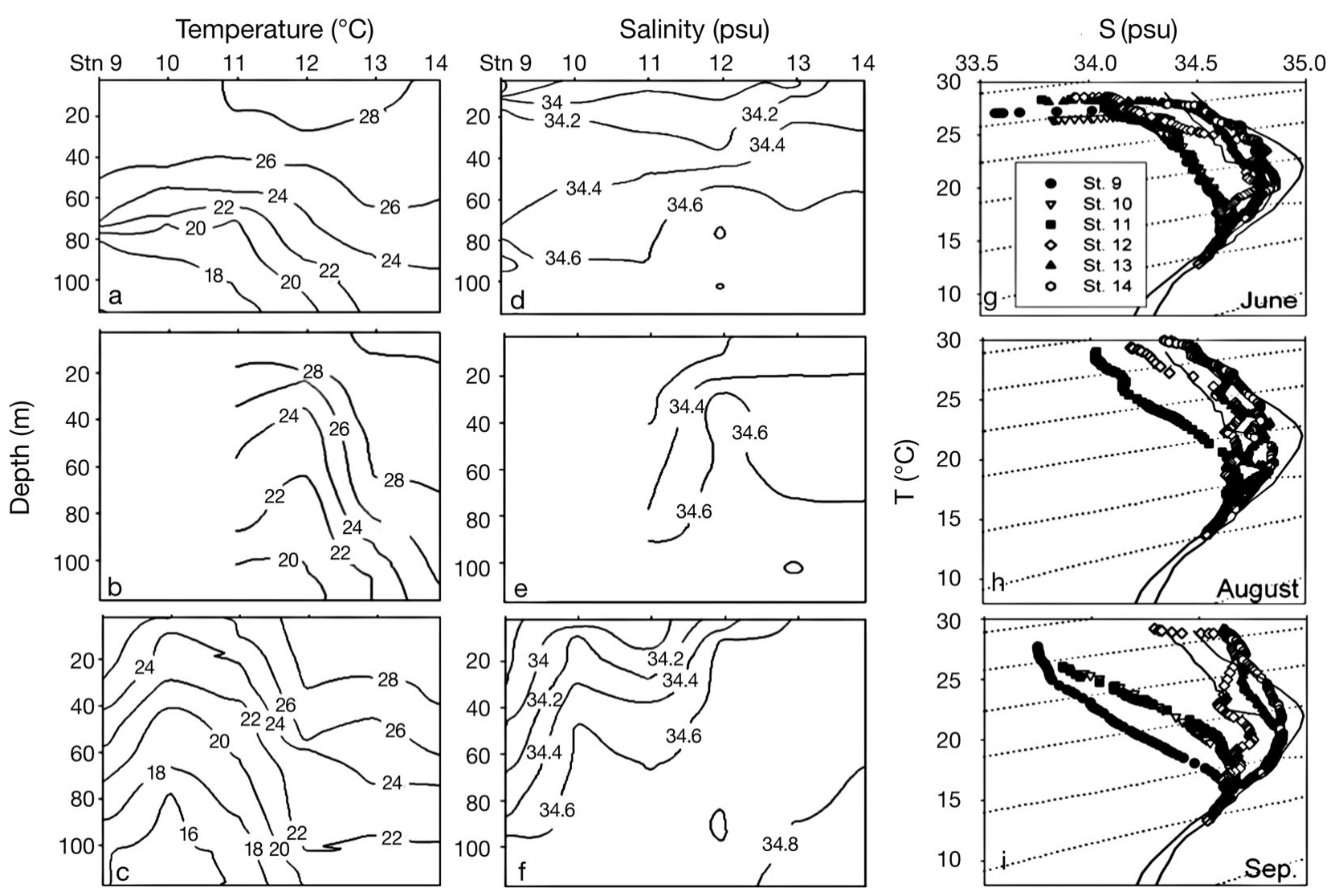

Fig. 2. Vertical sections of water temperature (T), salinity (S), and T-S diagrams during the 3 cruises in 2007. (a-c) Water temperature distributions, $(\mathrm{d}-\mathrm{f})$ salinity distributions, and $(\mathrm{g}-\mathrm{i}) \mathrm{T}-\mathrm{S}$ diagrams, in June, August and September. Curves in the T-S diagrams: mean characteristics of Kuroshio water based on historical records (Gong et al. 1995)

14 (Fig. 2b,e). The T-S curves showed a weak salinity front between Stns 11 and 13, and surface waters at Stns 11 and 12 were apparently mixtures of Kuroshio subsurface water and shelf water. On the other hand, T-S signatures of Stns 13 and 14 showed typical characteristics of Kuroshio surface water (Fig. 2h). Phosphate profiles during this cruise were very similar to those in June. The depth of the phosphocline was $\sim 5 \mathrm{~m}$ at Stn 11, and a weak phosphocline appeared below $100 \mathrm{~m}$ at Stn 14 (Fig. 3a,c). Nitrate and nitrite were undetectable at $3 \mathrm{~m}$ depth at Stn 11, but a high $3 \mu \mathrm{M}$ concentration was observed at $50 \mathrm{~m}$ (Table 1).

In September, a strong upwelling event was observed at Stn 10 (Fig. 2c). In the vertical section of salinity, higher salinities (>34.5 psu) were only observed near the Kuroshio (Fig. 2d-f). Vertical sections of temperature and salinity revealed a mixed layer $<10 \mathrm{~m}$ thick between Stns 9 and 11. The bottom of the mixed layer became deeper at Stns 12 and 13, and reached almost a 40 m depth at Stn 14 (Fig. 2c,f). The T-S curves were clearly divided into 2 groups with those from Stns 9 to 11 showing upwelling characteristics and those from Stns 12 to 14 showing Kuroshio characteristics (Fig. 2i). As a result, a sharp salinity front appeared be- tween Stns 11 and 13 (Fig. 2f). Compared to the other 2 cruises, the surface concentrations of phosphate and nitrate+nitrite at Stn 11 were higher in September, and the increasing trend of phosphate with depth was still evident (Table 1). At Stn 14, a similar stratification pattern was again detected with a phosphate nutracline appearing below $100 \mathrm{~m}$ (Fig. 3a,c).

\section{Chl $a$ and species composition of microphytoplankton}

The chl a concentrations in net-tow samples were $2 \times$ to $400 \times$ those in seawater, and microphytoplankton were greatly enriched by the plankton net (Table 2). In June, Trichodesmium spp. were the most dominant microphytoplankton in these concentrated samples, with abundances reaching 1850 and 1063 trichomes $\mathrm{ml}^{-1}$ at Stns 11 and 14, respectively. Diatoms were also abundant, with Chaetoceros spp., Rhizosolenia spp., and Bacteriastrum spp. dominating. On the other hand, dinoflagellates were a numerically minor group with cell numbers much lower than those of diatoms. The overall microphytoplankton compositions were similar for Stns 11 and 14. In August, microphytoplank- 
ton compositions did not change much from those in June. Trichodesmium spp. were still the most dominant group with somewhat lower abundances (325 to 350 trichomes $\mathrm{ml}^{-1}$ ), which increased diatom contribution to phytoplankton abundances (Table 2).
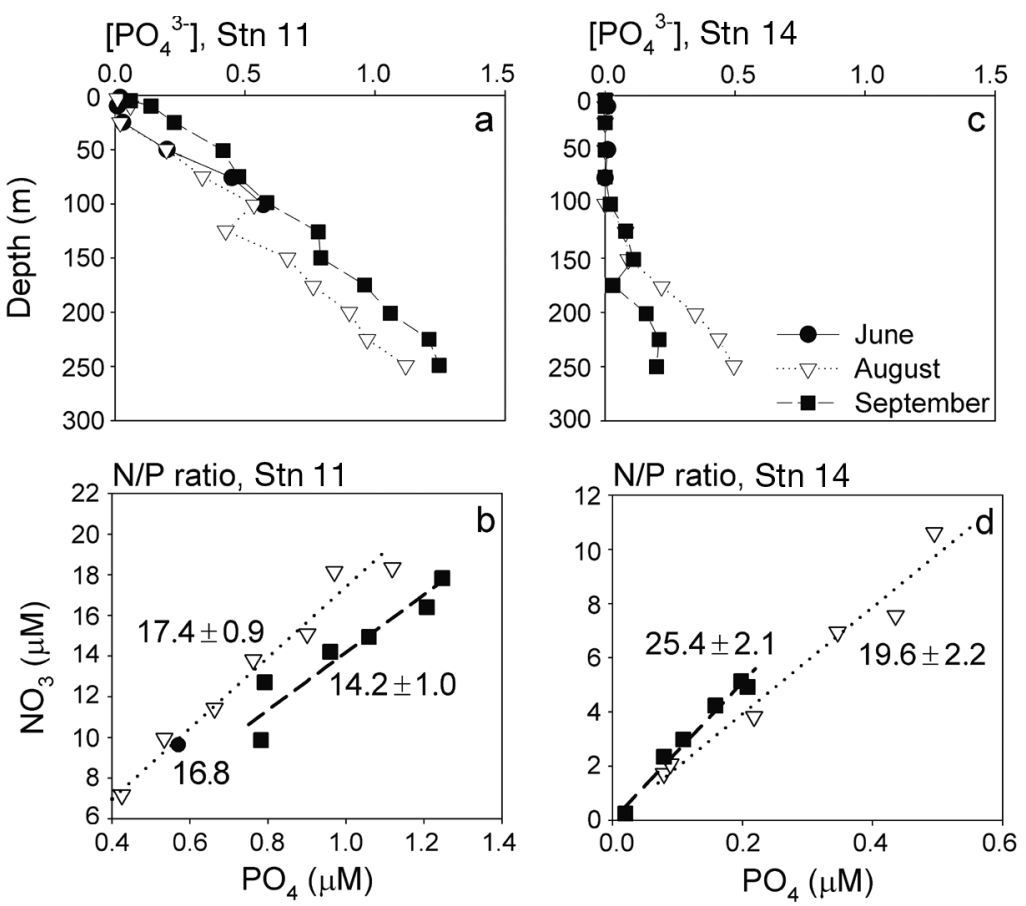

Fig. 3. Vertical profiles of phosphate concentrations $(\mu M)$ and N/P ratios below $100 \mathrm{~m}$ depth during the 3 cruises in 2007. Phosphate profiles for (a) Stn 11 (June, August and September), and (c) Stn 14 (August and September). Relationship between nitrate and phosphate concentrations below $100 \mathrm{~m}$ depth for (b) Stn 11 (only 1 measurement was taken during the June cruise), and (d) Stn 14. Numbers associated with individual regression lines: estimated N/P ratios $\pm 95 \%$ confidence interval
In September, Trichodesmium spp. were very abundant (5400 trichomes $\mathrm{ml}^{-1}$ ) at $3 \mathrm{~m}$ depth at Stn 9, but substantially decreased at Stn 12, and were absent from the net-tow sample of Stn 14 (Table 2). A similar trend was observed in diatoms. Although the towing time was fixed at $10 \mathrm{~min}$ for all stations, Trichodesmium and diatoms were difficult to collect at Stns 12 to 14 . In contrast, abundances of dinoflagellates remained more or less constant in the region between the upwelling center and the Kuroshio (Table 2). The contribution of dinoflagellates substantially increased in these samples containing low abundances of diatoms and filamentous cyanobacteria.

\section{$\mathrm{APA}$ and $F_{v} / F_{m}$}

Values of the maximal photochemical efficiency of PSII $\left(F_{V} / F_{m}\right)$ in June varied 0.32 to 0.45 in surface samples (Table 1). The highest value was observed in the upwelling region, and the lowest value in the Kuroshio region (Fig. 4a). In the $50 \mathrm{~m}$ samples, $F_{V} / F_{m}$ values were generally higher than those in surface samples (Fig. 4d). In June, APA surface values were 7.91 and 6.98 pmole $\mathrm{PO}_{4}{ }^{3-}(\mu \mathrm{g}$ chl a) ${ }^{-1} \mathrm{~min}^{-1}$ at Stns 11 and 14, higher than those observed in $50 \mathrm{~m}$ samples (Table 1, Fig. 4b,e). In August, the lowest $F_{V} / F_{m}$ value of surface samples was observed in the Kuroshio region (Table 1,

Table 1. Nutrient concentrations $(\mu \mathrm{M})$ and physiological indices of microphytoplankton at stations in the southern East China Sea during 3 cruises conducted in summer 2007. DIP: dissolved inorganic phosphate, $F_{V} / F_{m}$ : maximum quantum efficiency of photosynthesis, APA: alkaline phosphatase activity (pmol $\left.\mathrm{PO}_{4}{ }^{3-}[\mu \mathrm{g} \mathrm{chl} \mathrm{a}]^{-1} \mathrm{~min}^{-1}\right)$, nd: not detectable, $(-)$ : no sample taken

\begin{tabular}{|c|c|c|c|c|c|c|c|c|c|c|c|c|}
\hline \multirow{2}{*}{$\begin{array}{l}\text { Sample depth: } \\
\text { Station: }\end{array}$} & \multirow{2}{*}{9} & \multirow[b]{2}{*}{10} & \multirow{2}{*}{11} & \multirow{2}{*}{12} & \multirow[b]{2}{*}{13} & \multirow[b]{2}{*}{14} & \multirow[b]{2}{*}{9} & \multirow[b]{2}{*}{10} & \multirow{2}{*}{$\overline{11}$} & \multirow{2}{*}{12} & \multirow[b]{2}{*}{13} & \multirow[b]{2}{*}{14} \\
\hline & & & & & & & & & & & & \\
\hline \multicolumn{13}{|l|}{ June 2007} \\
\hline $\mathrm{NO}_{3}+\mathrm{NO}_{2}$ & nd & nd & nd & 0.10 & nd & 0.10 & 3.00 & 2.00 & 3.40 & 1.30 & 0.40 & 0.10 \\
\hline $\mathrm{DIP}(\mu \mathrm{M})$ & 0.07 & 0.08 & 0.02 & 0.01 & nd & nd & 0.19 & 0.10 & 0.20 & 0.07 & 0.06 & 0.01 \\
\hline$F_{V} / F_{m}$ & 0.34 & 0.39 & 0.45 & 0.36 & 0.40 & 0.32 & 0.51 & 0.39 & 0.48 & 0.54 & 0.51 & 0.39 \\
\hline APA & - & - & 7.91 & - & - & 6.98 & - & - & 1.41 & - & - & 2.71 \\
\hline \multicolumn{13}{|l|}{ August 2007} \\
\hline $\mathrm{NO}_{3}+\mathrm{NO}_{2}$ & - & - & nd & - & - & nd & - & - & 3.00 & - & - & 0.04 \\
\hline $\mathrm{DIP}(\mu \mathrm{M})$ & - & - & 0.01 & - & - & nd & - & - & 0.20 & - & - & nd \\
\hline$F_{V} / F_{m}$ & - & - & 0.38 & 0.33 & 0.36 & 0.28 & - & - & - & - & - & - \\
\hline APA & - & - & 9.56 & 3.49 & 7.06 & 3.81 & - & - & - & - & - & - \\
\hline \multicolumn{13}{|l|}{ September 2007} \\
\hline $\mathrm{NO}_{3}+\mathrm{NO}_{2}$ & nd & - & 0.25 & - & - & 0.01 & 7.30 & - & 6.09 & - & - & nd \\
\hline $\mathrm{DIP}(\mu \mathrm{M})$ & nd & - & 0.06 & - & - & nd & 0.38 & - & 0.42 & - & - & nd \\
\hline$F_{V} / F_{m}$ & 0.25 & 0.48 & 0.43 & 0.40 & 0.42 & 0.31 & 0.46 & 0.48 & 0.55 & 0.40 & 0.41 & 0.39 \\
\hline APA & 3.35 & 1.23 & 8.05 & 34.9 & 48.8 & 77.6 & 1.28 & 0.93 & 0.99 & 35.8 & 44.5 & 26.3 \\
\hline
\end{tabular}


Table 2. Chl a concentrations $\left(\mu \mathrm{g}^{-1}\right.$ ) and species compositions of net-collected microphytoplankton at stations in the southern East China Sea during 3 cruises conducted in summer 2007. Chl a was measured in both natural seawater (in situ) and net-collected samples (net-tow). Diatom and dinoflagellate abundances: cells $\mathrm{ml}^{-1}$, Trichodesmium spp. abundances: trichomes ml ${ }^{-1}$

\begin{tabular}{|c|c|c|c|c|c|c|c|c|c|c|c|c|c|c|c|c|}
\hline \multirow{2}{*}{$\begin{array}{l}\text { Month (depth): } \\
\text { Station: }\end{array}$} & \multicolumn{2}{|c|}{ June (3 m) } & \multicolumn{2}{|c|}{ August (3 m) } & \multicolumn{6}{|c|}{ - September $(3 \mathrm{~m})$} & \multicolumn{6}{|c|}{ - September $(50 \mathrm{~m})$} \\
\hline & 11 & 14 & 11 & 14 & 9 & 10 & 11 & 12 & 13 & 14 & 9 & 10 & 11 & 12 & 13 & 14 \\
\hline \multicolumn{17}{|l|}{ Chl a } \\
\hline In situ & 0.24 & 0.20 & 0.41 & 0.12 & 0.43 & 1.20 & 1.38 & 0.12 & 0.07 & 0.18 & 0.48 & 0.30 & 0.41 & 0.12 & 0.17 & 0.13 \\
\hline Net-tow & 71.4 & 55.8 & 27.9 & 8.59 & 188 & 93.1 & 15.1 & 2.37 & 2.08 & 0.37 & 69.4 & 84.8 & 33.4 & 0.99 & 1.90 & 1.67 \\
\hline \multicolumn{17}{|l|}{ Diatoms } \\
\hline Chaetoceros spp. & 750 & 613 & 813 & 213 & 325 & 1788 & 763 & 14 & 1.3 & 1.3 & 1075 & 1638 & 1575 & 88 & 20 & 13 \\
\hline Bacteriastrum spp. & 250 & 163 & 325 & 13 & 225 & 275 & 63 & 26 & 7.5 & 6.3 & 400 & 125 & 75 & 15 & 0 & 0 \\
\hline Rhizosolenia spp. & 263 & 363 & 100 & 0 & 738 & 163 & 25 & 0 & 2.3 & 0 & 288 & 38 & 25 & 0 & 13 & 13 \\
\hline Hemiaulus spp. & 75 & 38 & 138 & 38 & 188 & 150 & 0 & 36 & 16 & 10 & 138 & 88 & 88 & 2.5 & 2.5 & 3.8 \\
\hline Guinardia spp. & 38 & 63 & 25 & 0 & 338 & 50 & 0 & 0 & 1.2 & 0 & 175 & 50 & 0 & 13 & 1.3 & 0 \\
\hline Other species & 49 & 148 & 337 & 61 & 786 & 2974 & 437 & 14 & 15 & 4.9 & 574 & 2461 & 1237 & 46 & 17 & 36 \\
\hline \multicolumn{17}{|l|}{ Dinoflagellates } \\
\hline Ceratium spp. & 38 & 113 & 38 & 38 & 213 & 25 & 25 & 17 & 37 & 48 & 0 & 0 & 0 & 14 & 95 & 25 \\
\hline Dinophysis spp. & 25 & 0 & 13 & 0 & 0 & 0 & 13 & 8.8 & 3.8 & 0 & 0 & 13 & 0 & 3.8 & 2.5 & 1.3 \\
\hline Prorocentrum spp. & 0 & 0 & 0 & 13 & 63 & 25 & 75 & 0 & 20 & 8.8 & 25 & 38 & 0 & 7.5 & 14 & 10 \\
\hline Protoperidinium spp. & 175 & 88 & 25 & 663 & 238 & 75 & 25 & 30 & 39 & 21 & 25 & 38 & 13 & 43 & 30 & 111 \\
\hline Other species & 63 & 25 & 274 & 36 & 236 & 138 & 0 & 37 & 33 & 36 & 38 & 61 & 12 & 20 & 83 & 42 \\
\hline \multicolumn{17}{|l|}{ Cyanobacteria } \\
\hline Trichodesmium spp. & 1850 & 1063 & 350 & 325 & 5400 & 150 & 213 & 2.5 & 7.5 & 0 & 125 & 88 & 0 & 15 & 13 & 13 \\
\hline
\end{tabular}

Fig. 4a). APA values ranged from 3.49 to $9.56 \mathrm{pmol}$ $\mathrm{PO}_{4}{ }^{3-}(\mu \mathrm{g} \mathrm{chl} a)^{-1} \mathrm{~min}^{-1}$ in surface samples, and this range was similar to that observed in June (Fig. 4b). In September, the cross-shelf trend of surface $F_{V} / F_{m}$ resembled those in the 2 previous cruises (Table 1). High values occurred near the upwelling center, and low values occurred at stations far away from the upwelling center (Fig. 4a). Similarly, $F_{v} / F_{m}$ values in the $50 \mathrm{~m}$ samples were higher than in surface values. For APA values in September, 2 regions with very different trends were observed (Table 1). In both sur-

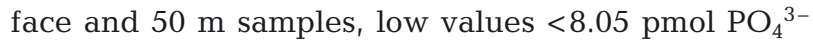
$(\mu \mathrm{g} \mathrm{chl} a)^{-1} \mathrm{~min}^{-1}$ were observed in the upwelling region (Stns 9 to 11), and high values $>26.3 \mathrm{pmol} \mathrm{PO}_{4}{ }^{3-}$ $(\mu \mathrm{g} \mathrm{chl} a)^{-1} \mathrm{~min}^{-1}$ were observed in the Kuroshio region (Stns 12 to 14) (Fig. 4c,f).

\section{DISCUSSION}

Our results indicate that upwelling is an important nutrient source for microphytoplankton in the outer shelf area. During the 3 cruises, the increasing trends of phosphate concentration at Stn 11 began at very shallow depths, which indicated an influence of upwelling (Fig. 3a). In contrast, phosphate profiles at Stn 14 showed strong stratification with deep nutraclines at depths $<100 \mathrm{~m}$ (Fig. 3c). As a result, nitrate and phosphate concentrations were always higher in the upwelling region than in the Kuroshio region (Table 1). In parallel with this pattern of nutrient distributions,
$F_{V} / F_{m}$ values of net-collected microphytoplankton revealed higher values near the upwelling center, which gradually decreased toward both ends of the cruise track (Fig. 4a). A nutrient deficiency was shown to cause low $F_{v} / F_{m}$ values in phytoplankton by impeding electron transport in the light reaction (Kolber \& Falkowski 1993, Wykoff et al. 1998), and Geider et al. (1993) observed that values of $F_{V} / F_{m}$ decreased from 0.6 to a range of $0.3-0.1$ when the diatom Phaeodactylum tricornutum was cultured in unbalanced growth conditions of phosphate, nitrate, and iron starvation. However, Parkhill et al. (2001) indicated that $F_{v} / F_{m}$ stayed high and constant when a diatom was acclimated to nutrient limitations under a status of balanced growth. Based on this information, low $F_{v} / F_{m}$ values at Stns 9 and 14 on September were likely a result of nutrient deficiencies under unbalanced growth. In contrast, high values in the upwelling region likely came from either nutrient-sufficient phytoplankton regardless of the growth modes, or nutrient-limited phytoplankton under balanced growth (Fig. 4a). At Stn 11, the high nutrient concentrations observed at $50 \mathrm{~m}$ depth indicated that both phosphorus and nitrogen were continuously being supplied by upwelling, which supports the nutrient-sufficient view (Fig. 4d).

The species composition is an important consideration in interpreting quantum efficiency data, and cyanobacteria are known to have lower $F_{v} / F_{m}$ values as they use phycobilisomes as the light-harvesting complex (Campbell et al. 1998). In our study area, the filamentous, nitrogen-fixing cyanobacteria Trichodes- 

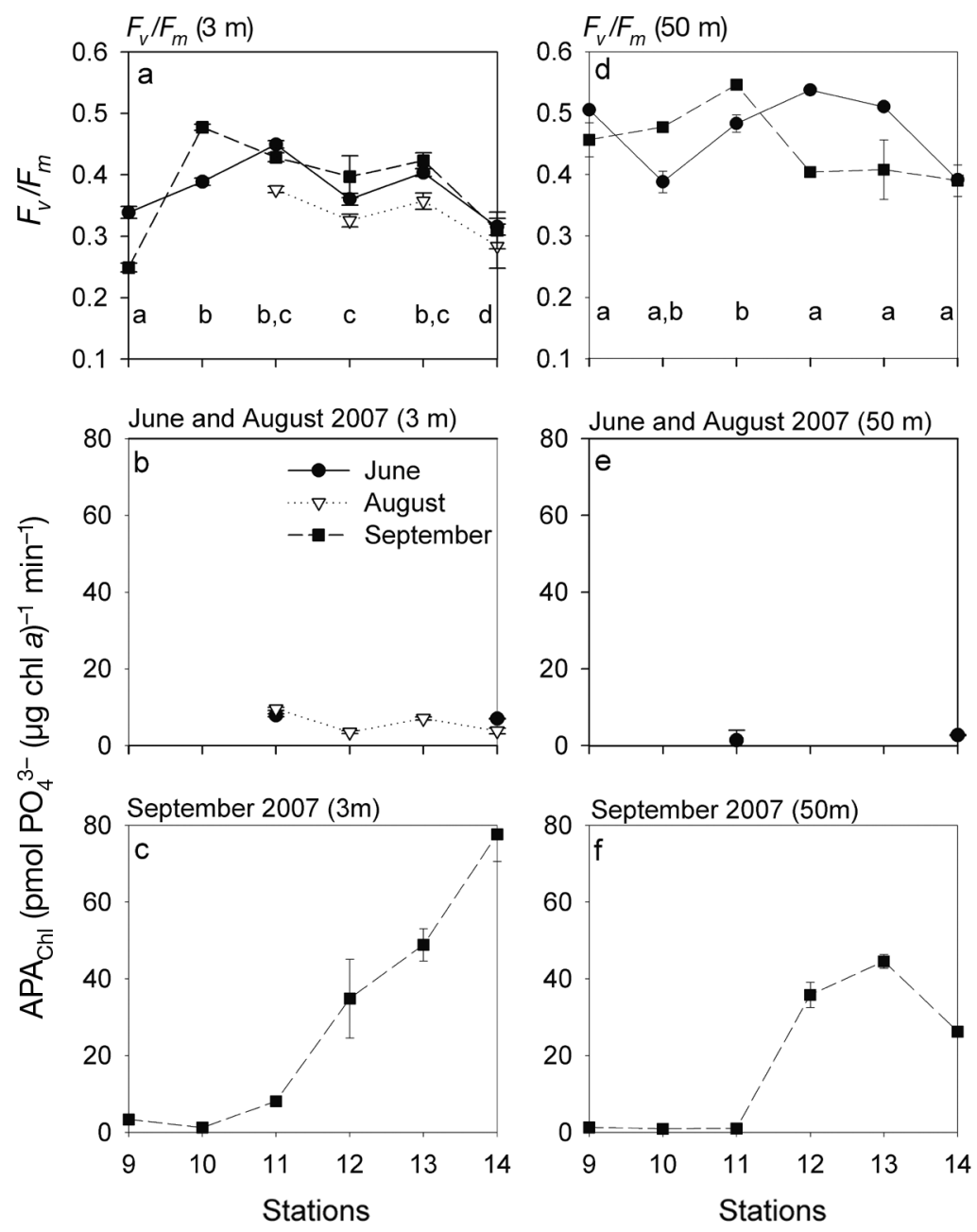

Fig. 4. Horizontal variations in alkaline phosphatase activity (APA) and the maximum quantum efficiency of photosynthesis $\left(F_{V} / F_{m}\right)$ at 2 depths during 3 cruises in summer 2007. (a,d) $F_{V} / F_{m}$ in June, August, and September, (b,e) APA in June and August, (c,f) APA in September. Error bars: \pm 1 SD $(n=3)$. Analysis of variance with multiple comparisons was performed on September $F_{V} / F_{m}$ values, and the same lowercase letters in (a) \& (d) indicate no significant difference at a level of $\alpha=0.05$

mium spp. were quite abundant, but their distribution did not properly explain the trends of $F_{V} / F_{m}$. On all 3 cruises, $F_{V} / F_{m}$ values at Stn 14 were consistently lower than corresponding values at Stn 11 in spite of the fact that the abundances of Trichodesmium were similar at these stations in June and August, and that Trichodesmium was absent from Stn 14 in September (Tables 1 \& 2). According to a study conducted in the Arafura and Timor Seas (Berman-Frank et al. 2001), $F_{V} / F_{m}$ values of Trichodesmium were especially low during a period of nitrogen fixation. If nitrogen fixation actively occurred in the Kuroshio region, it might cause the low $F_{V} / F_{m}$ values at $\operatorname{Stn} 14$ in June and August. However, this explanation apparently does not apply to the observation in September.
Low values of $F_{V} / F_{m}$ were not always accompanied by high APA (Fig. 4). In June and August, $F_{V} / F_{m}$ values ranged from 0.28 to 0.45 , but APA remained low, indicating that phosphorus utilization was not related to the quantum yield in photosynthesis (Figs. 4b \& 5a). In September, a negative correlation was observed between APA and $F_{V} / F_{m}$, suggesting that both were controlled by a common mechanism. Although APA values of dinoflagellates are generally higher than those of diatoms (Dyhrman \& Palenik 1999, Yamaguchi et al. 2005), the progressive increase in APA from Stns 12 to 14 was unlikely a result of variations in species composition since the abundances of dinoflagellates were similar at these stations (Table 1, Fig. 4f). The high APA at these stations was not a result of constitutive enzymes either, since the original APA of 26.3 to 77.6 pmol $\mathrm{PO}_{4}^{3-}$ $(\mu \mathrm{g} \quad \mathrm{chl} a)^{-1} \mathrm{~min}^{-1}$ was substantially lowered to 7.80 to 21.6 pmol $\mathrm{PO}_{4}{ }^{3-}$ ( $\mu \mathrm{g}$ chl a) ${ }^{-1} \min ^{-1}$ by the addition of extra orthophosphate (H. C. Liu unpubl. data). Another piece of supportive evidence comes from the virtual absence of Trichodesmium at Stns 12 to 14 in September. Since nitrogen is usually not a limiting nutrient for this organism, the disappearance of Trichodesmium implies that a nutrient other than nitrogen was insufficient, and made the Kuroshio an unsuitable environment for survival (Fig. 4f).

To some extent, ambient phosphate influences levels of APA. As long as phosphate concentrations in seawater exceeded the detection limit $(0.01 \mu \mathrm{M})$, all APA values were $<10 \mathrm{pmol} \mathrm{PO}_{4}{ }^{3-}(\mu \mathrm{g} \mathrm{chl} \mathrm{a})^{-1} \mathrm{~min}^{-1}$ (Fig. 5b). In contrast, samples with undetectable amounts of phosphate had a wide range of variation in APA from 3.35 to $77.6 \mathrm{pmol} \mathrm{PO}_{4}{ }^{3-}(\mu \mathrm{g} \mathrm{chl} a)^{-1} \mathrm{~min}^{-1}$. This inverse hyperbolic relationship has been repeatedly reported in the literature, and the phenomenon of low APA associated with low phosphate concentrations has been interpreted by a number of mechanisms, including intracellular storage of phosphate, turnover rates of phosphate in the water column, and the time required for the development of high APA (Dyhrman \& Ruttenberg 2006, Nicholson et al. 2006). In our study area, the high APA in September could not be attributed to a period of inactive upwelling since the opposite was indicated by the vertical section of tem- 


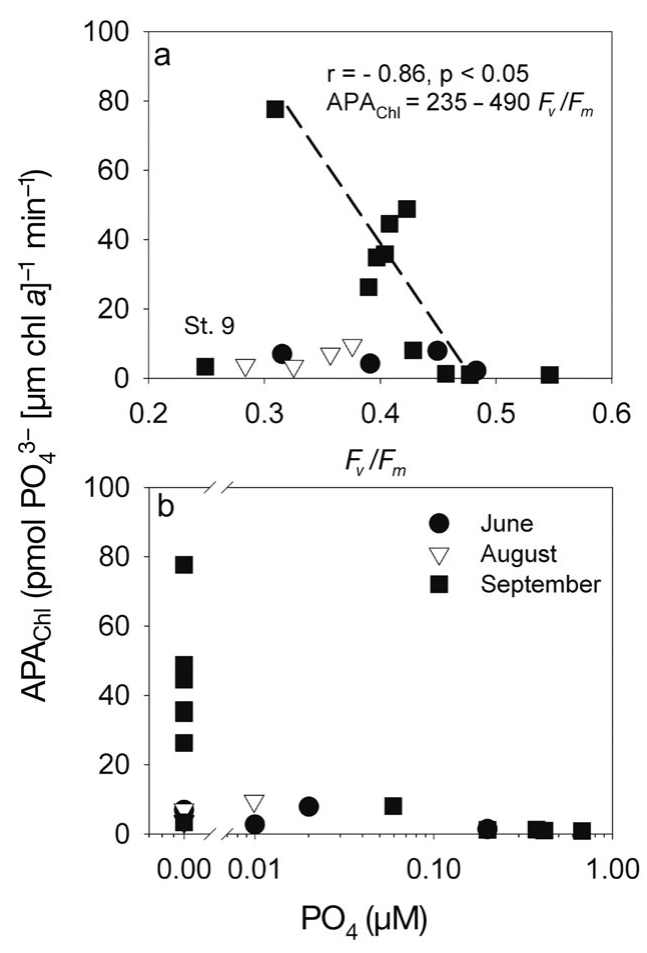

Fig. 5. Relationship between alkaline phosphatase activity (APA) and (a) the maximum quantum efficiency of photosynthesis $\left(F_{v} / F_{m}\right)$, and (b) ambient phosphate concentrations during 3 cruises in 2007. Dashed line in (a): principal axis of the equal-frequency ellipse in the correlation analysis for data obtained during the September cruise. A single outlier (Stn 9) was the data point at $3 \mathrm{~m}$ depth, and was excluded from the correlation analysis

perature (Fig. 2). Rather, high APA in Kuroshio waters was very likely caused by decreased horizontal water exchange between the Kuroshio and the upwelling region as discussed below.

In summer, a typical flow pattern in our study area involves a branch current that breaks off from the Kuroshio and develops a counterclockwise circulation around the upwelling area (Tang et al. 2000). This counterclockwise circulation may retain the upwelled water on the outer shelf for a period of time, and a satellite-tracked drifter was observed to be trapped in the upwelling region for $4 \mathrm{~d}$ before its entry into the main stream of the Kuroshio (Tseng \& Shen 2003). With the presence of this circulation pattern, a sharp front usually appears at the shelf-break, such as the one observed in September 2007, which caused drastic differences in hydrographic characteristics as well as microphytoplankton compositions across the front (Table 2, Fig. 2g-i). According to a calculation based on water and salt balances, shelf water contributed $<1 \%$ of the surface water at Stn 14 with the presence of a sharp front (Chen et al. 1995). This decreased water exchange must have reduced the nutrient supply from the upwelling, and high values of APA began to appear at Stn 14 (Fig. 4c-f).

On the other hand, the counterclockwise circulation is disturbed when the southwest monsoon periodically intensifies. The summer monsoon sends Taiwan Strait water across the continental shelf in summer, forming a layer of low-salinity water and temporarily suppressing the upwelling (Gong et al. 1992). This mixture of Taiwan Strait water and upwelled water had apparently reached Stn 14 during our June cruise, as indicated by a sharp turn on the T-S curve (Fig. 2g). In this situation, as much as $20 \%$ of the surface water at Stn 14 might have come from shelf water (Chen et al. 1995), and similar hydrographic characteristics and microphytoplankton compositions appeared at Stns 11 and 14 (Fig. 2g, Table 2). Low APA values observed in June and August 2007 implied adequate supplies of inorganic P (Fig. 4b,e).

Of course, vertical mixing inevitably provides part of the phosphorus for microphytoplankton in the Kuroshio area, but the amount has to be small. During these 3 cruises, nutraclines at Stn 14 consistently began at depths $<100 \mathrm{~m}$ (Fig. 3c), and upward diffusion would be difficult in summer when stratification is strong. In addition, the N/P ratio below $100 \mathrm{~m}$ was 25 in September, much higher than the Redfield ratio of 16 (Fig. 3d). Such a nutrient source with an unbalanced N/P ratio would have offered no remedy for the phosphate shortage even if a significant amount had reached the euphotic zone at Stn 14. An N/P ratio >16 in deep waters is common in regions with active nitrogen fixation (Arrigo 2005), and the segment of the Kuroshio in our study area was shown to contain substantial amounts of biologically fixed nitrogen based on isotope fractionation (Liu et al. 1996). Different N/P ratios observed in June, August, and September reflect distinctive combinations of nitrogen fixation, nutrient utilization, and regeneration ratio of N/P at different intensities, and these processes might have occurred in an upstream segment of Kuroshio instead of locally. When entering the overlying euphotic zone, these nutrients may have important effects on primary productivity and phytoplankton composition.

In conclusion, our results suggest that upwelling off the northeast coast of Taiwan is an important phosphorus source for microphytoplankton. When smooth horizontal water exchange between the upwelling and the Kuroshio occurs, microphytoplankton do not experience a phosphorus deficiency. In contrast, when the Kuroshio water is isolated from the upwelling by a steep frontal zone, upwelled inorganic P ceases to enter the Kuroshio area. In this circumstance, if phosphorus in the euphotic zone cannot be replenished from the deep water due to either a strong stratification or an unbalanced N/P ratio, microphytoplankton in the Kuroshio will begin to develop high APAs. 
Acknowledgements. We are grateful to the captain and crew of the RV 'Ocean Researcher II' for their assistance, to Dr. F.-K. Shiah for providing the FIRe fluorometer, to S.-H. Hung, L.-K. Kang, and Y.-L. Chen for their assistance with $F_{v} / F_{m}$ measurements, and to H.-F. Wang for her assistance with cell counts. Special thanks also go to Dr. M.-A. Lee and National Center for Ocean Research (Taiwan) for providing the image of sea surface temperatures. This study was supported in part by research grants (NSC94-2611-M-019-002 and NSC96-2313-B-019-006-MY3) from the National Science Council (Taiwan), and in part by funds from the Center for Marine Bioscience and Biotechnology, National Taiwan Ocean University.

\section{LITERATURE CITED}

Arrigo KR (2005) Marine microorganisms and global nutrient cycles. Nature 437:349-355

Berman-Frank I, Lundgren P, Chen YB, Küpper H, Kolber Z, Bergman B, Falkowski P (2001) Segregation of nitrogen fixation and oxygenic photosynthesis in the marine cyanobacterium Trichodesmium. Science 294:1534-1537

Campbell D, Hurry V, Clarke AK, Gustafsson P, Oquist G (1998) Chlorophyll fluorescence analysis of cyanobacterial photosynthesis and acclimation. Microbiol Mol Biol Rev 62:667-683

Cembella AD, Ania NJ, Harrison PJ (1982) The utilization of inorganic and organic phosphorous compounds as nutrients by eukaryotic microalgae: a multidisciplinary perspective: part 1. Crit Rev Microbiol 10:317-391

> Chang J (2000) Precision of different methods used for estimating the abundance of nitrogen-fixing marine cyanobacterium, Trichodesmium Ehrenberg. J Exp Mar Biol Ecol 245:215-224

Chen YLL (1994) The importance of temperature and nitrate to the distribution of phytoplankton in the Kuroshioinduced upwelling northeast of Taiwan. Proc Nat Sci Counc ROC Part B Life Sci 18:44-51

Chen YLL (2000) Comparisons of primary productivity and phytoplankton size structure in the marginal regions of southern East China Sea. Cont Shelf Res 20:437-458

Chen CTA, Ruo R, Pai SC, Liu CT, Wong GTF (1995) Exchange of water masses between the East China Sea and the Kuroshio off northeastern Taiwan. Cont Shelf Res 15: 19-39

Chen YLL, Lu HB, Shiah FK, Gong GC, Liu KK, Kanda J (1999) New production and f-ratio on the continental shelf of the East China Sea: comparisons between nitrate inputs from the subsurface Kuroshio current and the Changjiang River. Estuar Coast Shelf Sci 48:59-75

Chern CS, Wang J, Wang DP (1990) The exchange of Kuroshio and East China Sea shelf water. J Geophys Res 95:16017-16023

Chiang KP, Shiah FK, Gong GC (1997) Distribution of summer diatom assemblages in and around a local upwelling in the East China Sea northeast of Taiwan. Bot Bull Acad Sin 38:121-129

> Dugdale RC, Wilkerson FP, Hogue VE, Marchi A (2006) Nutrient controls on new production in the Bodega Bay, California, coastal upwelling plume. Deep-Sea Res II 53: 3049-3062

Dyhrman ST, Palenik B (1999) Phosphate stress in cultures and field populations of the dinoflagellate Prorocentrum minimum detected by a single-cell alkaline phosphatase assay. Appl Environ Microbiol 65:3205-3212

Dyhrman ST, Ruttenberg KC (2006) Presence and regulation of alkaline phosphatase activity in eukaryotic phytoplankton from the costal ocean: implications for dissolved organic phosphorous remineralization. Limnol Oceanogr 51:1381-1390

Dyhrman ST, Ammerman JW, Van Mooy BAS (2007) Microbes and the marine phosphorus cycle. Oceanography (Wash DC) 20:110-116

Falkowski PG (2002) The ocean's invisible forest. Sci Am 287:54-61

Geider RJ, Laroche J, Greene RM, Olaizola M (1993) Response of the photosynthetic apparatus of Phaeodactylum tricornutum (Bacillariophyceae) to nitrate, phosphate, or iron starvation. J Phycol 29:755-766

Gong GC, Shyu CZ, Shih WH, Liu KK (1992) Temperature fluctuation on the cold water off northern Taiwan: JuneDecember, 1990. Acta Oceanogr Taiwanica 28:118-127

Gong GC, Liu KK, Pai SC (1995) Prediction of nitrate concentration from two end member mixing in the southern East China Sea. Cont Shelf Res 15:827-842

Gong GC, Shiah FK, Liu KK, Wen YH, Liang MH (2000) Spatial and temporal variation of chlorophyll $a$, primary productivity and chemical hydrography in the southern East China Sea. Cont Shelf Res 20:411-436

Healey FP, Hendzel LL (1980) Physiological indicators of nutrient deficiency in lake phytoplankton. Can J Fish Aquat Sci 37:442-453

> Hung CC, Gong GC, Chung WC, Kuo WT, Lin FC (2009) Enhancement of particulate organic carbon export flux induced by atmospheric forcing in the subtropical oligotrophic northwest Pacific Ocean. Mar Chem 113:19-24

> Kiørboe T (1993) Turbulence, phytoplankton cell size, and the structure of food webs. Adv Mar Biol 29:1-72

Kokkinakis SA, Wheeler PA (1987) Nitrogen uptake and phytoplankton growth in coastal upwelling regions. Limnol Oceanogr 32:1112-1123

Kolber Z, Falkowski PG (1993) Use of active fluorescence to estimate phytoplankton photosynthesis in situ. Limnol Oceanogr 38:1646-1665

> Liu KK, Gong GC, Shyu CZ, Pai SC, Wei CL, Chao SY (1992) Response of Kuroshio upwelling to the onset of the northeast monsoon in the sea north of Taiwan: observations and a numerical simulation. J Geophys Res C 97:12511-12562

> Liu KK, Su MJ, Hsueh CR, Gong GC (1996) The nitrogen isotopic composition of nitrate in the Kuroshio water northeast of Taiwan: evidence for nitrogen fixation as a source of isotopically light nitrate. Mar Chem 54:273-292

Murphy J, Riley JP (1962) A modified single solution method for the determination of phosphate in natural waters. Anal Chim Acta 27:31-36

Nicholson D, Dyhrman S, Chavez F, Paytan A (2006) Alkaline phosphatase activity in the phytoplankton communities of Monterey Bay and San Francisco Bay. Limnol Oceanogr 51:874-883

Pai SC, Yang CC, Riley JP (1990) Effects of acidity and molybdate concentration on the kinetics of the formation of the phosphoantimonylmolybdenum blue complex. Anal Chim Acta 299:115-120

> Parkhill JP, Maillet G, Cullen JJ (2001) Fluorescence-based maximal quantum yield for PSII as a diagnostic of nutrient stress. J Phycol 37:517-529

> Perry MJ (1972) Alkaline phosphatase activity in subtropical central North Pacific waters using a sensitive fluorometric method. Mar Biol 15:113-119

> Perry MJ (1976) Phosphate utilization by an oceanic diatom in phosphorous-limited chemostat culture and in the oligotrophic waters of the central North Pacific. Limnol Oceanogr 21:88-107 
Ruttenberg KC, Dyhrman ST (2005) Temporal and spatial variability of dissolved organic and inorganic phosphorus, and metrics of phosphorus bioavailability in an upwellingdominated coastal system. J Geophys Res C 110:1-22

Sebastián M, Niell FX (2004) Alkaline phosphatase activity in marine oligotrophic environments: implications of singlesubstrate addition assays for potential activity estimations. Mar Ecol Prog Ser 277:285-290

Smayda TJ (1974) Some experiments on the sinking characteristics of two freshwater diatoms. Limnol Oceanogr 19:628-635

Smith REH, Kalff J (1981) The effect of phosphorus limitation on algal growth rates: evidence from alkaline phosphatase. Can J Fish Aquat Sci 38:1421-1427

Smith SV, Kimmerer WJ, Walsh TW (1986) Vertical flux and biogeochemical turnover regulate nutrient limitation of net organic production in the North Pacific Gyre. Limnol Oceanogr 31:161-167

Takahashi MT, Ishizaka J, Ishimaru T, Atkinson LP and others (1986) Temporal change in nutrient concentrations and phytoplankton biomass in short time scale local upwelling around the Izu Peninsula, Japan. J Plankton Res 8: 1039-1049

Editorial responsibility: Hans Heinrich Janssen, Oldendorf/Luhe, Germany
Tang TY, Tai JH, Yang YJ (2000) The flow pattern north of Taiwan and the migration of Kuroshio. Cont Shelf Res 20: 349-371

Tomas CR (ed) (1996) Identifying marine diatom and dinoflagellates. Academic Press, San Diego, CA

Tseng RS, Shen YT (2003) Lagrangian observations of surface flow patterns in the vicinity of Taiwan. Deep-Sea Res 50: $1107-1115$

Villareal TA (1992) Buoyancy properties of the giant diatom Ethmodiscus. J Plankton Res 14:459-463

Welschmeyer NA (1994) Fluorometric analysis of chlorophyll $a$ in the presence of chlorophyll $b$ and pheopigments. Limnol Oceanogr 39:1985-1992

Wykoff DD, Davies JP, Melis A, Grossman AR (1998) The regulation of photosynthetic electron transport during nutrient deprivation in Chlamydomonas reinhardtii. Plant Physiol 117:129-139

Yamaguchi H, Sakou H, Fukami K, Adachi M, Yamaguchi M, Nishijima T (2005) Utilization of organic phosphorus and production of alkaline phosphatase by the marine phytoplankton, Heterocapsa circularisquama, Fibrocapsa japonica and Chaetoceros ceratosporum. Plankton Biol Ecol 52:67-75

Submitted: July 29, 2009; Accepted: March 29, 2010

Proofs received from author(s): June 10, 2010 